\title{
EMPLOYEE TURNOVER CLASSIFICATION USING PSO-BASED NAÏVE BAYES AND NAÏVE BAYES ALGORITHM IN PT. MASTERSYSTEM INFOTAMA
}

\author{
Endang Sri Palupi \\ Sistem Informasi \\ Universitas Bina Sarana Informatika \\ www.bsi.ac.id \\ endang.epl@bsi.ac.id
}

\begin{abstract}
Abstrak
Turnover yang terjadi karena banyak karyawan yang keluar dan karyawan yang baru masuk, sehingga perputaran keluar masuk karyawan cukup tinggi, karena itu turnover dapat dikendalikan dengan strategi peningkatan engagement karyawan. PT. Mastersystem Infotama adalah sebuah perusahaan System Integrator atau lebih dikenal dengan perusahaan IT yang cukup besar dengan jumlah karyawan keseluruhan kurang lebih 600 karyawan. Turnover yang cukup tinggi membuat beberapa divisi kekurangan sumber daya manusia, dan divisi human capital management cukup kesulitan melakukan perekrutan karyawan untuk mencari kandidat dengan berbagai kriteria yang harus tersedia dalam waktu singkat. Persaingan dunia IT cukup ketat baik dalam perusahaan ataupun karyawan dengan pengalaman dan kemampuan yang sudah bagus. Terutama bagian sales yang memegang database para customer yang potensial, dan bagian engineer yang sudah mempunyai sertifikat keahlian yang banyak digunakan dalam dunia bisnis IT. Oleh karena itu perlu diklasifikasi faktor apa saja yang membuat tingginya turnover karyawan dengan menggunakan algoritma Naïve Bayes dan Naïve Bayes berbasis Particle Swarm Optimization, sehingga bisa menjadi bahan evaluasi internal untuk meningkatkan engagement karyawan. Hasil penelitian ini klasifikasi menggunakan algoritma Naïve Bayes akurasinya sebesar $79.17 \%$ sedangkan klasifikasi menggunakan algoritma Nä̈ve Bayes berbasis Particle Swarm Optimization sebesar 94.17\%.
\end{abstract}

Kata kunci: Algoritma Naïve Bayes, Particle Swarm Optimization, Turnover

\begin{abstract}
Turnover occurs because many employees leave and new employees enter, so the turnover in and out of employees is quite high, therefore turnover can be controlled with a strategy to increase employee engagement. PT. Mastersystem Infotama is a System Integrator company or better known as a fairly large IT company with a total of approximately 600 employees. Turnover is high enough to make some divisions lack human resources, and the human capital management division is quite difficult to recruit employees to find candidates with various criteria that must be available in a short time. Competition in the IT world is quite tight both within companies and employees with good experience and abilities. Especially the sales department that holds a database of potential customers, and the engineer section that already has a certificate of expertise that is widely used in the IT business world. Therefore, it is necessary to classify what factors make employee turnover high by using the Naïve Bayes and Naïve Bayes algorithms based on Particle Swarm Optimization, so that they can be used as material for internal evaluation to increase employee engagement. The results of this study, classification using the Naïve Bayes algorithm, has an accuracy of 79.17\%, while the classification using the Naïve Bayes algorithm based on Particle Swarm Optimization is $94.17 \%$.
\end{abstract}

Keywords: Algoritma Naïve Bayes, Particle Swarm Optimization, Turnover

\section{INTRODUCTION}

The employee turnover rate in a company which is measured based on the number of workers in a certain period or known as high turnover is a serious problem at PT Mastersystem Infotama. With the increase in turnover, many projects are delayed or the team dismantles so that the project is not 
completed on time. Recruiting new employees is timeconsuming and costly, has to be by the specifications of the requirements, skills according to the positions required, not to mention the adaptation of employees to the current work system. For this reason, the company wants to minimize the turnover that occurs by improving several matters related to career development, company regulations, bonuses and incentives, the applicable system, and other policies. It is expected that after that the turnover rate at the company will decrease so that it can achieve the company's goals and targets well, and be able to compete with competing companies. (Noviyanto, 2018)

In previous research written by Stefani Arika Noviyanti in a thesis entitled Employee Turnover Prediction Using the Naïve Bayes Classification Method in 2018, to predict employees who will resign in 2019. The results of this study are used for the development of employee planning so that they can assist in achieving the target company. Meanwhile, the authors classify the turnover factors that occur, so that they can make better human resource development plans and increase employee engagement to reduce turnover. (Noviyanto, 2018)

In 2018 there was also research and was stated in a journal entitled Classification of Employee Status Determination Using the Naïve Bayes Method written by Fattya Ariani and friends. This study uses five attributes, namely: attendance, attitude, psychological test, interview, and appointment. The attributes used as labels are lifted. The result is that manual calculation and the use of Rapidminer yield the same values. The value of $c 1$ (lifted) is 0.567 , while the value of $\mathrm{c} 2$ (not lifted) is 0.433 . And the highest value is elevated. The difference with this study is that the authors classify the turnover factor, although many employees are appointed as permanent employees if the high turnover rate is futile and they have to recruit new employees again so that it takes time and operational costs. (Ariani et al., 2018)

Another research was conducted by Taufik Asra in 2019 with the title Comparison of C4.5, K-NN, and Naïve Bayes Algorithms in Employee Admission Using PSO at PT. XYZ. This study calculates employee acceptance in the company by comparing 3 algorithms, namely C4., K-NN, and Naïve Bayes. The result is the highest level of accuracy in the calculation with the Naïve Bayes algorithm optimized with PSO with an accuracy rate of $91.25 \%$. The difference with the author's research is that the author uses the Naïve Bayes algorithm and the PSO-based Naïve Bayes algorithm and the authors classify the turnover factors that occur in the company. (Asra, 2019)

Another journal that discusses classification using the Naïve Bayes algorithm in 2015 by Alfa Saleh with the title Implementation of the Naïve Bayes Classification Method in Predicting the Amount of Household Electricity Usage. This study uses 60 data on electricity users and the results are accurate with a percentage of $78.333 \%$ of the 60 data on electricity users, 47 electricity users have been classified correctly. The author uses more employee data, namely 400 permanent employee data so that more data can be classified. (Saleh, 2015)

The journal entitled Decision Support System for Determining Employee Monthly Incentives Using the Naïve Bayes Method was written by Victor Marudut Mulia Siregar in 2018. This study aims to determine the number of employee incentives and implemented them in a Microsoft Visual Studio 2013 application. The results of the calculation use the Naïve Algorithm method. Bayes is accurate and can be used to calculate appropriate incentives for each employee. The difference with this study is that the authors classify employee turnover using the Naïve Bayes Algorithm Method. (Marudut et al., 2018)

Then in the journal written by Taufik Asra in 2019 entitled Comparison of C4.5, K-NN and Naïve Bayes Algorithms in Employee Admission using PSO at PT. XYZ, the result has the highest accuracy using the Naïve Bayes algorithm, optimized with PSO, which is $91.25 \%$. The difference with this journal is that the authors classify employee turnover while in this study the comparison of employee acceptance and the author only uses the Naïve Bayes Algorithm and PSObased Naïve Bayes Algorithm. (Asra, 2019)

The journal with the title Decision Making for Non-Permanent Employees to Become Permanent Employees with a Decision Tree was written by Febryantahauji and friends in 2018. This journal uses the C4.5 Decision Tree Algorithm for the selection of permanent employee admissions. This study only uses the Decision Tree C4.5 Algorithm method, there is no comparison. The purpose of this research is to avoid naughty people in the appointment of permanent employees so that the company gets qualified employees, while this study aims to classify employee turnover so that the company can create programs to increase employee engagement. (Sembiring, 2018)

The journal entitled Prediction of Employee Promotion with the C4.5 Algorithm (Case Study: Senayan Jakarta Apartments) was written by Sunarti in 2019. The results of the study were $78 \%$ accurate using the C4.5 algorithm. This journal only uses the C4.5 Algorithm method and its purpose is to predict employee promotions. Meanwhile, the authors compared the Naïve Bayes Algorithm with the PSObased Naïve Bayes Algorithm to classify employee turnover. (Sunarti, 2019) 
Furthermore, the journal entitled Prediction of Loyalty in Employee Engagement with the Company Using the C4.5 Algorithm (Case Study of PT. XYZ) was written by Bayu Ferdiansyah and Leonard Goeirmanto in 2020. The study conducted a loyalty survey using EES (Employee Engagement Survey) with the google form application, for the question using excel. Using the C4.5 Algorithm to predict employee engagement loyalty using 1002 sample data. The result of accuracy is $90.11 \%$ with the statement that employees are not loyal to the company. This research uses only one algorithm, C4.5, with no comparison with other algorithms and does not use PSO optimization. (Bayu Ferdiansyah, 2020)

The next journal entitled Application of Employee Status Classification Using the Naïve Bayes Algorithm Method at H. Syaiful Anwar Hospital was written by Rino Guphita in 2018. This research is to classify the status of new employees using variables of education level, work experience, and basic salary. This study only uses one Naïve Bayes Algorithm method and does not use PSO optimization. This research is also implemented using PHP and MySQL platforms. (Rino Gupitha, 2018)

The research entitled Factors Affecting Turnover Intention of Employees at PT. Mandiri Tunas Finance Bengkulu was written by Andriyani Prawitasari in 2005. The results of this study the factors that influence turnover are: age, length of work, education, attachment to the company, job satisfaction with the company, corporate culture. The author uses these factors as data attributes. The difference is that the authors calculate the accuracy of these factors. (Prawitasari, 2016)

The next journal reference is the journal entitled Comparison of Employee Acceptance Analysis Using the C4.5 Algorithm, K-NN, and PSOBased Naïve Bayes. This research was written by Ayuni Asistyasari and Yosep Nuryaman in 2019 by comparing the 3 algorithms used according to the journal title. The result of the lowest order accuracy is the classification using the $\mathrm{C} 4.5$ algorithm based on PSO $86.25 \%$, then the second classification uses the PSO-based K-NN algorithm the accuracy value is $82.50 \%$, and the last one with the highest accuracy is the classification using the Naïve Bayes algorithm. based on PSO with an accuracy value of $91.25 \%$. Classification using the PSO-based Naïve Bayes algorithm produces high scores as well as this study. (Asistyasari, 2019)

The journal entitled Determination of Work Schedule Based on Employee Data Classification Using the C4.5 Decision Tree Method (Case Study of the University of Muhammadiyah Surabaya) was written in 2016 by Triuli Novianti and Iwan Santosa. This journal discusses determining employee work schedules based on classification using the C4.5 Decision Tree Algorithm. The final result of all data using cross-validation 5 fold the accuracy is $70 \%$. The journal only uses one algorithm, namely the Decision Tree Algorithm C4.5 without using PSO optimization so that there is no comparison of the results with other algorithms. (Triuli Novianti, 2016)

The next journal entitled Determination of Overtime Schedule with Classification of Employee Data Using the C4.5 Algorithm was written by Ikhsan Romli and Ahmad Turmudi Zy pda in 2020. This research was made to determine employee overtime schedules and the results were 91\% accuracy with $86.05 \%$ precision and 92 recall. 5\%. This study only uses one C4.5 Algorithm without using PSO optimization, while the authors use PSO optimization for comparisons. (Ikhsan Romli, 2020)

The next reference is the journal entitled Naïve Bayes Algorithm Analysis for Classification of Exemplary Employees at PT. Toyoseal Indonesia, written by Chandra Naya and Muhlisin in 2019. This study determines exemplary and non-exemplary employees (performance) in a company with 5 attributes, 160 data, and with only one algorithm method, namely Naïve Bayes with an accuracy of 81.25\%, Precision $77.78 \%$ and Recall $87.50 \%$. This research does not use optimization so there is no comparison to compare the results of its accuracy. (Chandra Naya, 2019)

In 2019 Deni Anugrah Sahputra and friends wrote a journal entitled Determining the Eligibility Factors for Employee Admission Using the Decision Tree Algorithm at PT. Outsourcing Personnel. With the amount of data as many as 19163 candidates who applied in 2019, using the Decision Tree Algorithm resulted in an accuracy of $73.27 \%$ and an AUC value of 0.789 . The most influential recruitment eligibility factors are references from friends, age from 26-30 years old, female gender, for Office Services positions, domiciled in Jabodetabek, and undergraduate education level. This study only uses one algorithm, namely the Decision Tree, so there is no comparison for comparisons and does not use PSO optimization. (Sahputra \& Saelan, 2020)

The purpose of this study is to classify the turnover factor at PT. Mastersystem Infotama so that the Human Capital Management section can change the system or work program so that it can reduce the turnover rate at the company. With the decrease in the turnover rate, the employee's commitment to the company increases, saves time and costs for the recruitment of new employees, and employees last a long time to work at the PT Mastersystem Infotama company, so that all employees can more easily work together with the company to achieve targets and goals. 


\section{RESEARCH METHODS}

This study uses the CRISP-DM (CrossIndustry standard process for Data Mining) model. The Cross-Industry Standard Process for Data Mining (CRISP-DM) was developed in 1996 by analysts from several industries. CRISP-DM provides a standard data mining process for solving general problems of business or research units. (Daniel T. Larose, 2005)

CRISP-DM stands for Cross-Industry Standard Process Model for Data Mining, which describes the data mining process in 6 stages.

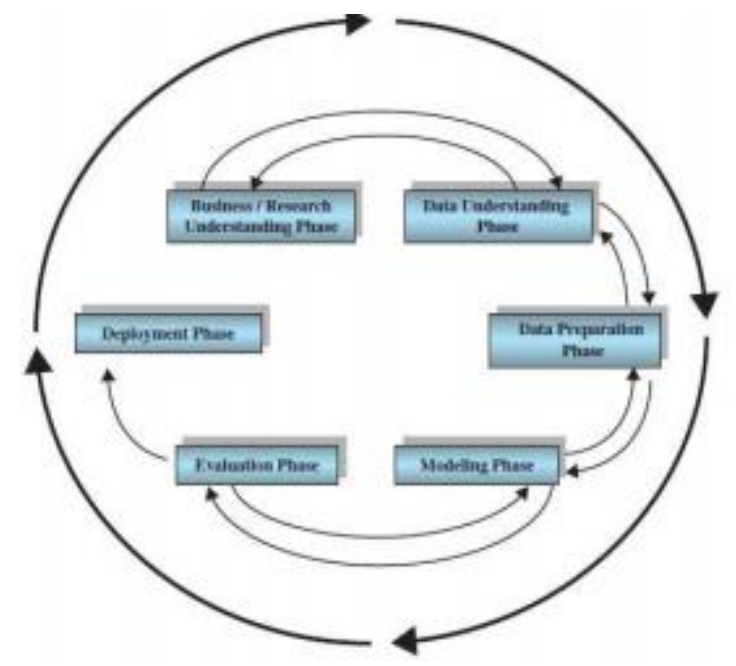

Figure 1. Stages of CRISP-DM (Larose, 2014)

\section{Business Understanding}

Base on figure 1. Stages of CRIPS-DM, the purpose of this study is to classify the turnover factors that occur in the company. It is hoped that the company can make a better work program and a more conducive office atmosphere, increase employee engagement with the company, and make employees feel more comfortable so that the turnover rate decreases. Reduced turnover can reduce the budget for recruiting employees, running projects are not interrupted due to changes or lack of resources, sales last a long time so that good relationship with customers are well maintained because they are maintained with the same people.

\section{Data Understanding}

At this stage, the authors take the employee data from the HCM section plus the results of the employee satisfaction survey at the company via a google form. Data of 400 employees and only taken from employee data with permanent employee status, employees with contract status, and data from outsourcing is not taken.

\section{Data Preparation}

After all, data has been collected there are several useless attributes that must be removed using Remove Useless Attributes, after the Remove Useless Attributes process in the Rapid Miner Studio Framework, the attributes used in the data are: Name, age, years of service, education, the value of satisfaction with the company, loyalty, KPI and survive or not.

\section{Modelling}

In this phase, the authors conducted modeling using the Rapid Miner Studio Framework with the Naïve Bayes Algorithm and the PSO-based Naïve Bayes Algorithm. First, the author uses the Validation function and the Naïve Bayes Algorithm to get the accuracy and AUC values. Then the two authors used the Validation function and the PSO-based Naïve Bayes Algorithm to get the accuracy value and AUC as a comparison.

\section{Evaluation}

At this stage, the authors evaluate the results of the modeling phase and the results using the PSObased Validation function and Naïve Bayes Algorithm to get the accuracy value and the AUC results are better using PSO optimization.

\section{Deployment}

The best result of modeling is to use the Naïve Bayes Algorithm based on Particle Swarm Optimization with an accuracy value of $81.32 \%$ and an AUC value of 0.837 . The use of PSO increases the classification accuracy value for weighting the Naïve Bayes Algorithm.

\section{Types of research}

This research uses qualitative methods with case studies at PT. Mastersystem Infotama is a system integrator company in Jakarta. Against the background of the high turnover rate at the company, which could hinder the company from achieving its target.

\section{Time and Place of Research}

This research was conducted in February 2019 at PT Mastersystem Infotama in Central Jakarta. The author is an employee of the company, making it easier for permission and access to conduct observations and research to obtain data.

\section{Research Target / Subject}

The subjects of this study were employees at PT. Mastersystem Infotama, to classify what factors cause high turnover rates. Researchers conducted 
observations, research, and interviews between office hours and during breaks.

\section{Procedure}

This framework represents the steps and procedures that will be carried out in this research process. The research framework can be described in the following figure:

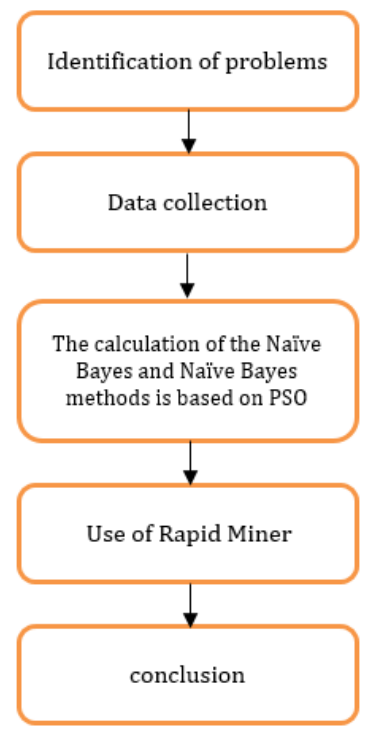

Figure 2. Research Framework (RYFA, 2020)

1. Identification of Problems

By figure 2. the research framework in the identification of the problem, the problem is determining the turnover factor classification pattern so that the turnover rate decreases to achieve the company's target well.

2. Data Collection

At the data collection stage in figure 2. research framework, the data used are the results of observations, research, interviews, and from the company what is the turnover rate that occurred in 2018.

3. Manual data processing using the Naïve Bayes method

The next step is shown in Figure 2 of the research framework, which is processing data using the Naïve Bayes method. This step performs manual calculations using the Naïve Bayes formula from the data that has been obtained.

4. Data processing using Rapid Miner

Then next is the use of the Rapid Miner application using the Naïve Bayes algorithm operation according to the steps in Figure 2 of the research framework.

5. Conclusion
The last stage in the research framework stage is a conclusion. The conclusion is obtained after getting the results from both manual data processing and also using Rapid Miner. (Ariani et al., 2018)

\section{Data, Instruments, and Data Collection} Techniques

The author obtained data from the company's human capital management division in the form of 400 employee data. Then the authors also conducted literature studies, observations, and interviews.

1. Literature study

Collect literature, data, good information from scientific journals, books, websites, and magazines.

2. Observation

Read and observe directly at the company where you research how the work system is happening every day so far.

3. Interview

Interview with employee correspondents who work at the research company, what obstacles are often faced, what factors cause employees to want to resign, as well as confirm the results of the data obtained from observations. (RYFA, 2020)

\section{Data analysis technique}

Quantitative research, in general, can be described as scientific research that is used to test a theory, using a theory consisting of variables and models, analyzed and measured by statistical numbers.

In this study, the authors used quantitative data analysis techniques, namely observation and interviews with employees to find out why the turnover rate was high, what factors caused turnover. The author also obtained employee data as many as 400 permanent employee data.

It is hoped that with this research the human capital management division can implement and implement policies that can reduce employee turnover so that all employees and the company can work together to achieve goals and targets.

\section{RESULTS AND DISCUSSION}

Model Testing with the Naïve Bayes Algorithm using employee data with permanent employee status in 2018 as many as 400 employee data. 


\section{Information Gain Feature Selection Process}

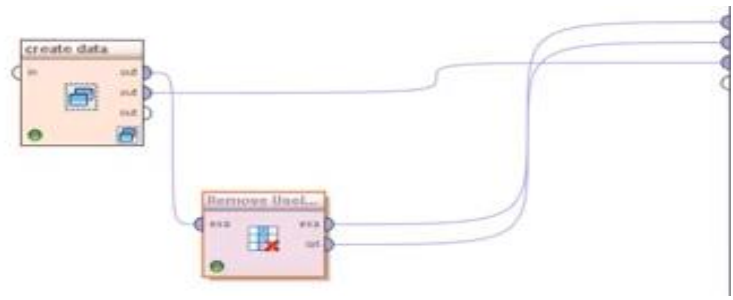

Figure 3. Remove Useless Attributes

After the dataset is available, the next step is to remove unused attributes using the Remove Useless Attributes operator in the RapidMiner Studio
Framework. As in Figure 3 using the useless attributes function in the RapidMiner Studio Framework.

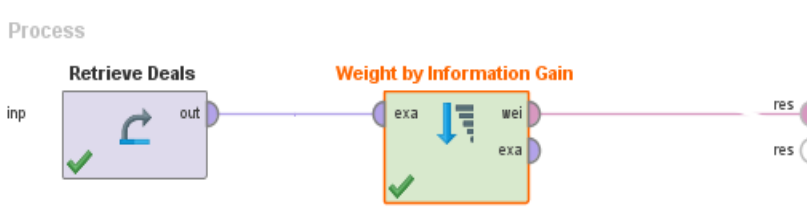

Figure 4. Information Gain

Furthermore, in Figure 4. the information gain, the authors weighting using the Information Gain operator on the FrameWork RapidMiner Studio.

Table 1. Employee Data

\begin{tabular}{|c|c|c|c|c|c|c|c|}
\hline NAME & AGE & $\begin{array}{c}\text { YEARS OF } \\
\text { SERVICES } \\
\text { (YEAR) }\end{array}$ & EDUCATION & $\begin{array}{c}\text { VALUE OF } \\
\text { SATISFACTION } \\
\text { TO THE } \\
\text { COMPANY } \\
\end{array}$ & LOYALTY & KPI & STAY \\
\hline Edi Bakhtiar & 57 & 14 & DIPLOMA & Good & Good & Good & Yes \\
\hline Endang Sri Palupi & 38 & 7 & MAGISTER & Good & Good & Good & Yes \\
\hline Yanto Susanto & 55 & 14 & HIGH SCHOOL & Good & Average & Average & No \\
\hline Alex Yusuf Efendy & 40 & 14 & MAGISTER & Average & Good & Not Good & No \\
\hline Shanti Cecilia & 42 & 14 & DIPLOMA & Good & Average & Good & Yes \\
\hline Nadia Rahmawati & 35 & 14 & DIPLOMA & Not Good & Good & Average & No \\
\hline Cecilia Fang & 39 & 14 & BACHELOR & Average & Good & Not Good & No \\
\hline Kevin Aryanti & 32 & 14 & DIPLOMA & Good & Good & Good & Yes \\
\hline Ari Baharudin & 35 & 14 & BACHELOR & Good & Good & Average & Yes \\
\hline Aryo Nugrohon & 30 & 13 & BACHELOR & Not Good & Average & Not Good & No \\
\hline Budi Susanto & 29 & 14 & BACHELOR & Not Good & Good & Average & No \\
\hline Paulus Alexander & 26 & 13 & BACHELOR & Good & Average & Average & No \\
\hline Anita Nurhasanah & 23 & 14 & HIGH SCHOOL & Good & Average & Good & Yes \\
\hline Siti Azarah & 22 & 13 & HIGH SCHOOL & Good & Good & Good & Yes \\
\hline Muhammad Dzikra & 27 & 14 & BACHELOR & Not Good & Good & Average & No \\
\hline Ryan Nurwahid & 24 & 13 & DIPLOMA & Average & Not Good & Average & No \\
\hline Putra Muhammad Hadi & 24 & 13 & BACHELOR & Average & Not Good & Average & No \\
\hline Rachmat Setiawan & 29 & 13 & HIGH SCHOOL & Good & Good & Good & Yes \\
\hline Wawan Cahyadi & 32 & 13 & MAGISTER & Good & Good & Good & Yes \\
\hline Fika Taulani Sari & 24 & 13 & BACHELOR & Good & Average & Good & Yes \\
\hline Alfin Dwi Iswinantyo & 23 & 12 & BACHELOR & Good & Not Good & Average & No \\
\hline Susi Yulianti & 22 & 12 & HIGH SCHOOL & Good & Average & Not Good & No \\
\hline Felicia Cecilia Que & 27 & 12 & BACHELOR & Not Good & Good & Not Good & No \\
\hline
\end{tabular}

After the process of removing unused attributes with the operator, removing useless attributes, and weighting them with the Information Gain operator, this is the employee data that is ready for use in table 1. employee data,

\section{Naïve Bayes classification}

In figure 5. Design of the Naïve Bayes Algorithm Model, creating a model design using the Naïve Bayes Algorithm using the Rapid Miner Studio Framework.

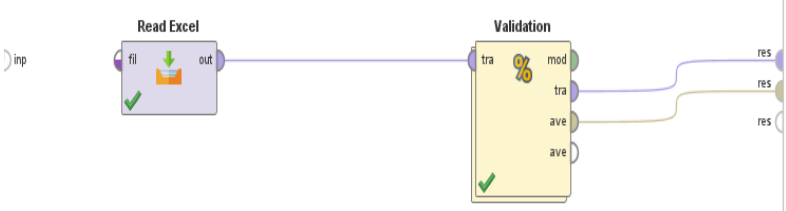

Figure 5. Design of the Naïve Bayes Algorithm Model

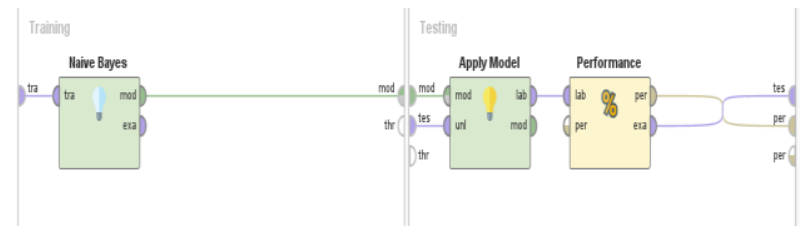

Figure 6. Validation of the Naïve Bayes Algorithm

Figure 6. Validation of the Naïve Bayes Algorithm is a validation modeling using the Naïve Bayes Algorithm using the Rapid Miner Studio Framework.

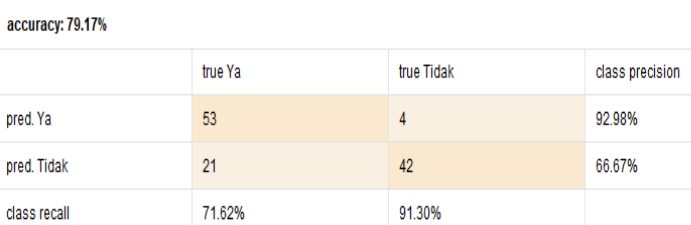

Figure 7. Accuracy of the Naïve Bayes Algorithm Method 
Figure 7. Accuracy of the Naïve Bayes Algorithm Method is modeling using the Naïve Bayes algorithm using the Rapid Miner Studio Framework

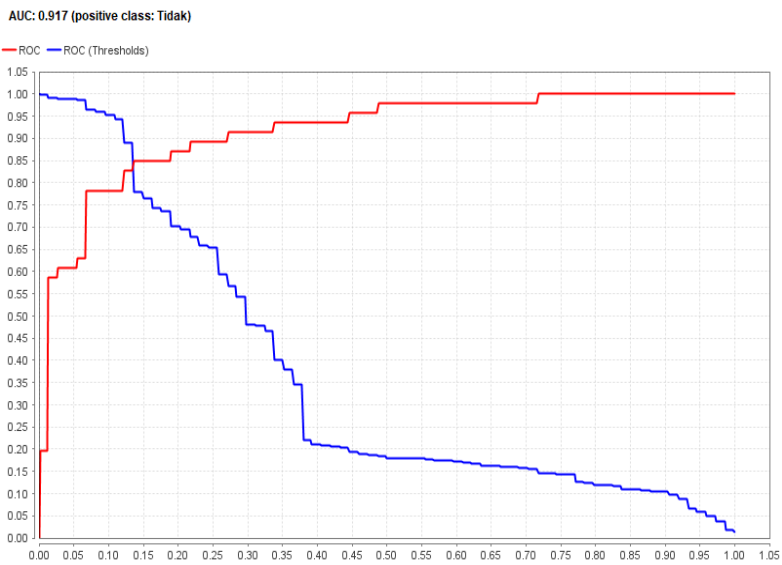

Figure 8. Area Under ROC Curve

Base on the figure 8 area under the ROC curve, the AUC value of 0.917 is a good classification category.

\section{Naïve Bayes classification}

Then we will create a model design using the PSO-based Naïve Bayes Algorithm using the Rapid Miner Studio Framework.

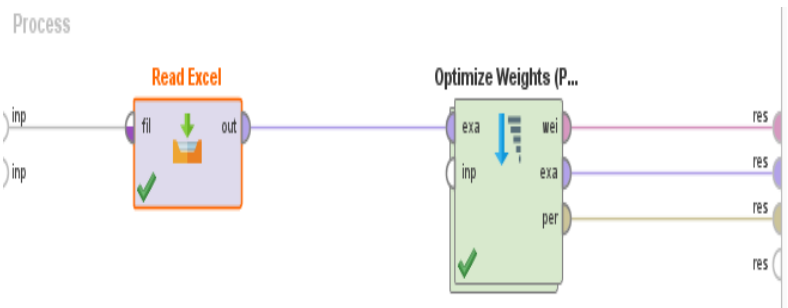

Figure 9. Design of the Naïve Bayes Algorithm Model Based on Particle Swarm Optimization

Figure 9 is the Naïve Bayes Algorithm modeling design that is optimized using Particle Swarm Optimization in the Rapid Miner Studio Framework.

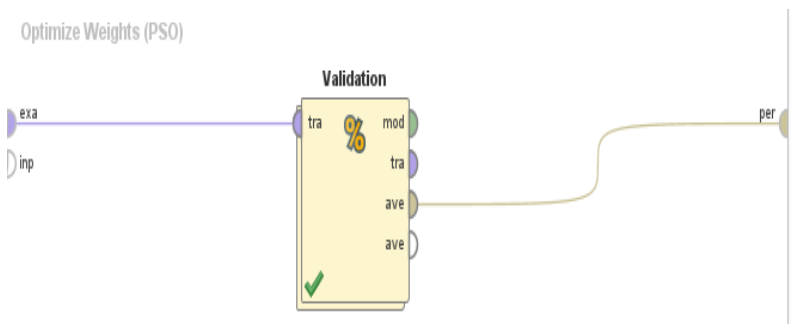

Figure 10. Particle Swarm Optimization Process
Figure 10 is the process of using Particle Swarm Optimization in the RapidMiner Studio Framework.

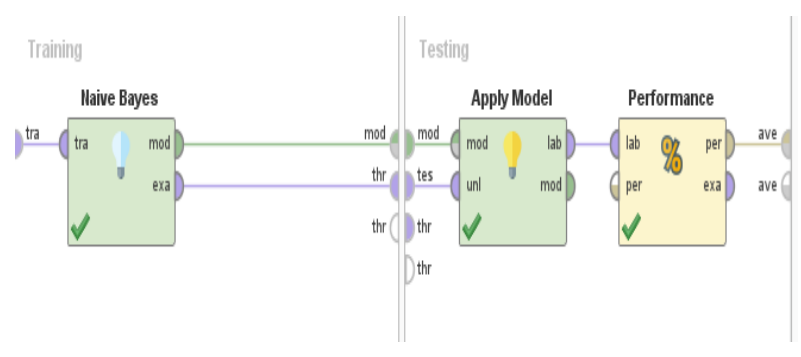

Figure 11. Validation of the Naïve Bayes Algorithm Based on Particle Swarm Optimization

Figure 11 is the validation process of the Naïve Bayes Algorithm based on Particle Swarm Optimization using the Rapid Miner Studio Framework

\begin{tabular}{|l|l|l|l|}
\hline accuracy: $94.17 \%$ & & & \\
\hline & true $Y_{a}$ & true Tidak & class precision \\
\hline pred. Ya & 69 & 2 & $97.18 \%$ \\
\hline pred. Tidak & 5 & 44 & $89.80 \%$ \\
\hline class recall & $93.24 \%$ & $95.65 \%$ & \\
\hline
\end{tabular}

Figure 12. Accuracy of the Naïve Bayes Algorithm Method Based on Particle Swarm Optimization

Base on figure 12 the results of the accuracy using the Naïve Bayes Algorithm Method Based on Particle Swarm Optimization amounted to $94.17 \%$.

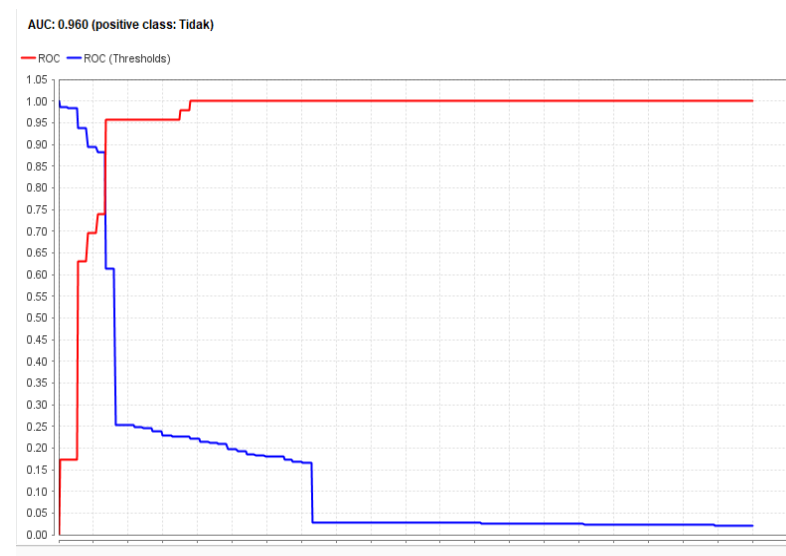

Figure 13. Area Under ROC Curve

The AUC value of 0.960 is a good classification category. 


\section{CONCLUSIONS AND SUGGESTIONS}

\section{Conclusion}

The results of the classification of the Naïve Bayes Algorithm have an accuracy of $79.17 \%, 66.67 \%$ precision, $91.30 \%$ recall, and AUC 0.917 . While the classification uses the Naïve Bayes Algorithm method based on Particle Swarm Optimization with an accuracy of $94.17 .32 \%, 89.80 \%$ precision, $95.65 \%$ recall, and 0.960 AUC. From the results, it can be seen that the PSO-based Naïve Bayes Algorithm method has better accuracy than using the Naïve Bayes Algorithm method alone.

\section{Suggestion}

For further research, you can use bigger attributes and more data. Can use other algorithms that are optimized with Particle Swarm Optimization so that the accuracy value is more perfect.

\section{REFERENCES}

Ariani, F., Amir, Alam, N., \& Rizal, K. (2018). Klasifikasi Penetapan Status Karyawan Dengan Menggunakan Metode Naive Bayes. Jurnal Paradigma, $\quad X X(2), \quad 33-38$ https://doi.org/10.31294/p.v

Asistyasari, A. N. Y. (2019). Komparasi Analisis Penerimaan Karyawan Menggunakan. November, 519-525. https://doi.org/10.30998/simponi.v0i0.519

Asra, T. (2019). Komparasi Algoritma C4.5, K-NN Dan Naïve Bayes Dalam Penerimaan Karyawan Menggunakan PSO Pada PT. XYZ. Indonesian Journal on Software Engineering (IJSE), 5(2), 7179. https://doi.org/10.31294/ijse.v5i2.6959

Bayu Ferdiansyah, L. goeirmanto. (2020). Prediksi Loyalitas dalam Keterikatan Karyawan terhadap Perusahaan Menggunakan Algoritma. Jurnal Sistem Dan Teknologi Informasi, 8(1), 8797.

Chandra Naya, M. (2019). Analisa Algoritma Naïve Bayes Untuk Klasifikasi Karyawan Teladan Pada PT. Toyoseal Indonesia. SIGMA - Jurnal Teknologi Pelita Bangsa, 10(2407-3903), 3945.

Herry Derajad, W (2020). Implementasi Data Mining Dengan Algoritma Naïve Bayes Pada Penjualan Obat. Jurnal Informatika, Vol 7 No 1 April, 1-7.

Ikhsan Romli, A. T. Z. (2020). Penentuan Jadwal Overtime Dengan Klasifikasi Data Karyawan Menggunakan Algoritma C4.5. Jurnal Sains Komputer \& Informatika (J-SAKTI), 4(September), 694-702.

Larose, D. T. (2014). Discovering Knowledge in Data: An Introduction to Data Mining. (I. New Jersey:
John Wiley \& Sons (ed.)).

Marudut, V., Siregar, M., Komputer, T., Indonesia, P. B., Utara, S., Cafe, E. S., Cafe, S., \& Cafe, E. S. (2018). Sistem Pendukung Keputusan Penentuan Insentif Bulanan Pegawai Dengan Menggunakan Metode Naïve Bayes. 7, 87-94.

Noviyanto, A. S. (2018). Prekdiksi Turnover Karyawan Menggunakan Metode Klasifikasi Naive Bayes. V.

Prawitasari, A. (2016). Faktor-Faktor Yang Mempengaruhi Turnover Intention Karyawan Pada Pt. Mandiri Tunas Finance Bengkulu. EKOMBIS REVIEW: Jurnal Ilmiah Ekonomi Dan Bisnis, 4(2), 177-186. https://doi.org/10.37676/ekombis.v4i2.283

Rino Gupitha. (2018). Penerapan Klasifikasi Status Pegawai Menggunakan Metode Naïve Bayes Kajian Teori Penelitian Terkait. Jurnal Global, $V(1), 28-38$.

RYFA. (2020). Teknik Pengumpulan Data Kualitatif dan Kuantitatif dalam Metode Penelitian. https://kumparan.com/berita-update/teknikpengumpulan-data-kualitatif-dan-kuantitatifdalam-metode-penelitian-1ukfvn1FWGs/full

Sahputra, D. A., \& Saelan, M. R. R. (2020). Penentuan Faktor Kelayakan Penerimaan Karyawan Menggunakan Algoritma Decission Tree pada Perusahaan PT . Personel Alih Daya. Jurnal Sains Dan Informatika, 6(November), 148-156. https://doi.org/10.34128/jsi.v6i2.225

Saleh, A. (2015). Implementasi Metode Klasifikasi Naïve Bayes Dalam Memprediksi Besarnya Penggunaan Listrik Rumah Tangga. Creative Information Technology Journal, 2(3), 207-217.

Sembiring, I. (2018). Pengambilan keputusan pegawai tidak tetap menjadi pegawai tetap dengan decission tree. Journal of Informatics Education, 1, 26-37.

Sugiyono. (2013). Metode Penelitian Kuantitatif, Kualitatif dan $R \& D$.

Sunarti. (2019). Prediksi Promosi Jabatan Karyawan Dengan Algoritma C4 . 5 ( Studi Kasus: Apartemen Senayan Jakarta ). Techno.Com, 18(4), 288-298.

Triuli Novianti, I. S. (2016). Penentuan Jadwal Kerja Berdasarkan Klasifikasi Data Karyawan Menggunakan Metode Decision Tree C4 . 5 ( Studi Kasus Universitas Muhammadiyah Surabaya). Jurnal Komunikasi, Media Dan Informatika, 5(1). 